BEFORE MARX: SOCIALISM AND COMMUNISM IN FRANCE, 1830-48 
Also by Paul E. Corcoran POLITICAL LANGUAGE AND RHETORIC 


\section{BEFORE MARX: SOCIALISM AND COMMUNISM IN FRANCE, 1830-48}

Edited by

Paul E. Corcoran

Senior Lecturer in Politics

University of Adelaide

Adelaide, South Australia

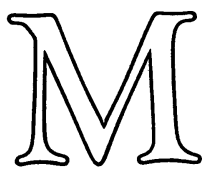


(C) Paul E. Corcoran 1983

Softcover reprint of the hardcover 1st edition 1983 978-0-333-31498-2

All rights reserved. No part of this publication may be reproduced or transmitted, in any form or by any means,

without permission

First published 1983 by

THE MACMILLAN PRESS LTD

London and Basingstoke

Companies and representatives

throughout the world

ISBN 978-1-349-17148-4

ISBN 978-1-349-17146-0 (eBook) DOI 10.1007/978-1-349-17146-0 


\section{To the memory of \\ Annie Barlow Corcoran}




\section{Contents}

Preface ix

Introduction 1

PART I RADICAL SOCIALISTS AND COMMUNISTS

1. Louis-Auguste Blanqui: Oath of Membership into the Société des Saisons (1830) 33

Defence before the Court of Assizes (1832) 36

2. Richard Lahautière: A Brief Catechism of Social Reform (1839)

3. Théodore Dézamy: Philosophy of the Current Crisis (1840)

4. Jean-Jacques Pillot: The People (1840) 68

5. The First Communist Banquet (1840) 72

6. Étienne Cabet: Communist Propaganda (1842) 80

\section{PART II WORKING CLASS SOCIALISTS AND} UNIONISTS

7. Émile Varin: To All (1839) 93

8. L. J. Vannostal: To the Workers (1840) 98

9. Lenoir: What Progress Is and What It Is Not (1840) 101

10. Flora Tristan: To Working Men and Working Women (1843)

\section{PART III POLITICAL ECONOMISTS}

11. Jules Leroux: Political Economy Considered as a Science (1833)

12. J. C. L. Simonde de Sismondi: Of Landed Wealth (1834)

13. Victor Considérant: The New Feudalism (1843) 153

14. Constantin Pecqueur: Free Trade (1846) 


\section{PART IV UTOPIAN PUBLICISTS}

15. Jules Lechevalier: Of Association (1834)

16. Victor Considérant: Pre-requisite for the Legitimacy of a Social Doctrine (1836)

17. Théodore Dézamy: Laws of the Community (1842)

PART V RELIGIOUS AND PHILOSOPHICAL SOCIALISTS

18. Prosper Enfantin: To Saint-Simonians Far Away From Paris (1830)

19. Pierre Leroux: Of Philosophy and Christianity (1832) 206

20. Alphonse Esquiros: The Gospel of the People (1840) 213

21. Alphonse Constant: The Bible of Liberty (1841) 220

$\begin{array}{ll}\text { Bibliography } & 224\end{array}$

Index 


\section{Preface}

The central aim of this book is to bring for the first time to the English reader an original documentation of socialism and communism in France when the movement was in its creative stage and earliest phase of popular propaganda. This is to rule out, from the outset, socialist thought of a later period, when it had developed into an international political movement and the writings and organisational efforts of Karl Marx had been stamped indelibly upon the tradition. This documentation is comprised of selected texts from a wide range of radical political literature in France between 1830 and 1848 . The authors of these articles, tracts, defence briefs, workers' writings and other rare items are largely unknown to modern English, indeed even French, scholarship. The texts have never been translated into English, and very few of them are available in French apart from their original publication.

The guiding interest of this collection is the presentation of the ideas, as well as the rhetorical style, of early French socialism. The materials presented here are intended to provide answers to questions that have been largely overlooked by the literature which has focused on Marxist thought and the socialist movement so closely associated with his works. What were the central ideas, themes and issues of the original socialist movement? Upon what intellectual and political sources did it draw? How did the movement articulate itself, and to whom? Who were the leading figures, and what kind of men and women were they? What did it mean to be a 'socialist' or a 'communist' in the original sense before the establishment of political parties? What literary and political strategies were undertaken?

Part of the interest of this study must inevitably be the context it provides for the development of Marx's thought. He arrived in Paris in 1843 , at the age of 25 , having only begun to read socialist writings (from France) the year before. During his stay in France, and then later in Belgium, his growing familiarity with socialism derived from his encounter with the very literature represented in 
this book. Marx's first book, La Misère de la philosophie (1847) was written in French, and composed in reply to one of the leading figures of the French socialist movement, Pierre-Joseph Proudhon. The coincidence of Marx's entry upon an already active socialist movement is interesting in several obvious respects, although that coincidence has been very badly explored. The claim by both Marx and Friederich Engels that French socialism was a utopian movement led by petty bourgeois intellectuals, dreamers, third-rate thinkers and madmen with no understanding of economics or class struggle has gone largely unchallenged by Marxist and non-Marxist scholars alike. It is hoped that the present study will demonstrate that the 'scientific' and German philosophical expression which Marx and Engels managed to give to socialism has not only distorted the work of earlier socialists, but has also obscured the radical aims and the innovative critical methods developed by the French thinkers. Several other preconceptions will also be shaken. For example, the early French thinkers regarded socialism as a peculiarly French tradition, dating from the Revolution and originally inspired by Rousseau. Marx's view that the French socialists were, at least from his own time forward, an intellectual nullity because of their lack of neo-Hegelian historicism and materialism left the French cold, and Marx snubbed. The few foreign influences the French socialists recognised were exclusively British in origin, and this influence was specifically economic and empirical in character. These supposed 'utopians' were oblivious or scornful of Hegelian philosophy, and were only aware of it in the later propaganda of the Saint-Simonian society, which sank because of its penchant for metaphysical eschatology. Finally, the reader of early French socialist literature will discover that it was far more profoundly romantic in character than it was utopian. Indeed, socialism and romanticism were widely understood to be a single intellectual and political movement in the 1830 s and 1840 s - a fact which accounts for the commitment to communicate directly to the masses in their own language. This also explains the movement's devotion to the people and revulsion at capitalist industrialism, while celebrating the commune, the recovery of an organically harmonious community and the role that science must play in revolutionising the economy.

The texts presented here will also provide a documentation of the ideas for which Marx and Engels, as well as later historians, give passing credit to French socialists and communists. These translations show, for example, that the ideas of social class and class 
struggle were common currency by the early 1840s. Such terms as proletariat and capitalist were in use, and were understood to refer to classes which were forming in inexorable opposition as the result of laisser-faire government policy and ruthless free enterprise. The working class was understood to embody the revolutionary strength necessary to uproot the established order and build a new society. Private property was the essence of the old order, and it must be destroyed, along with the institutions it supported. Religion, education and the family must all be refashioned in order to promote a population both capable and desirous of socialist community. The liberal political regime of their own day was an empty superfice of an underlying rule of capitalist wealth; government in the socialist community would simply become irrelevant and eventually disappear.

It has become the fate of the early socialist thinkers to become 'precursors' or 'pre-Marxist' thinkers. The major thinkers in this category - Saint-Simon, Fourier and Proudhon - have been denominated the 'French utopian socialists', the 'true utopians' as Engels called them, and the rest have by and large been forgotten altogether, or relegated to footnotes. These minor figures, and still others who have been entirely unknown, have been restored to a moment's notice in this book in the hope that the reader today may perceive some of that early character of socialism that has been forgotten and, perhaps unfortunately, lost.

My translations from the French endeavour to render the original meanings and rhetorical style of each author as carefully as possible. I have been conservative in the introduction of contemporary political and economic idioms, resorting to these only when clarity would otherwise be lost. I have not tried to be faithful to the variety of emphases originally achieved by the use of upper case lettering and contrasting typefaces. It has been my impression that rendering many of these texts from the French has required a lowering of tone and a cooling of ardour, although these qualities have been retained to a degree which I trust will be conducive to the sympathy and understanding of the English reader.

My interest in this subject grew out of a period of study in Paris at the Bibliotheque nationale, where the original documents are held by virtue of the continuous tradition of that institution as the legal depository of all French publications. I also benefited from a period 
of study at the Firestone Library of Princeton University, where my efforts were encouraged by Stanley Kelley and Wilbur Samuel Howell. My acknowledgements should also be extended to the University of Adelaide for granting me a generous period of study leave to undertake the research, and for the encouragement of my colleagues there. A special word of appreciation is due to Christine Hill for typing the manuscript in several drafts with efficiency and good cheer.

\section{Adelaide}

Paul E. Corcoran

South Australia 